\title{
Developing a regulatory framework for the financial, management performance and social reporting systems for co-operatives in developing countries: A case study of South Africa
}

\begin{tabular}{|c|c|}
\hline \multicolumn{2}{|c|}{$\begin{array}{l}\text { Authors: } \\
\text { Gideon Nieman }{ }^{1} \\
\text { Karel Fouché }^{2}\end{array}$} \\
\hline \multicolumn{2}{|c|}{$\begin{array}{l}\text { Affiliations: } \\
{ }^{1} \text { Department of Business } \\
\text { Management, University of } \\
\text { Pretoria, South Africa }\end{array}$} \\
\hline \multicolumn{2}{|c|}{$\begin{array}{l}{ }^{2} \text { Department of Auditing, } \\
\text { University of Pretoria, } \\
\text { South Africa }\end{array}$} \\
\hline \multicolumn{2}{|c|}{$\begin{array}{l}\text { Corresponding author: } \\
\text { Karel Fouché, } \\
\text { karel.fouche@up.ac.za }\end{array}$} \\
\hline \multicolumn{2}{|c|}{$\begin{array}{l}\text { Dates: } \\
\text { Received: } 02 \text { Sept. } 2014 \\
\text { Accepted: } 10 \text { Nov. } 2015 \\
\text { Published: } 31 \text { Aug. } 2016\end{array}$} \\
\hline \multicolumn{2}{|c|}{$\begin{array}{l}\text { How to cite this article: } \\
\text { Nieman, G. \& Fouché, K., } \\
2016, \text { 'Developing a } \\
\text { regulatory framework for the } \\
\text { financial, management } \\
\text { performance and social } \\
\text { reporting systems for } \\
\text { co-operatives in developing } \\
\text { countries: A case study of } \\
\text { South Africa', Acta Commercii } \\
16(1), \text { a285. http://dx.doi. } \\
\text { org/10.4102/ac.v16i1.285 }\end{array}$} \\
\hline \multicolumn{2}{|c|}{$\begin{array}{l}\text { Copyright: } \\
\text { (C) 2016. The Authors. } \\
\text { Licensee: AOSIS. This wo } \\
\text { is licensed under the } \\
\text { Creative Commons } \\
\text { Attribution License. }\end{array}$} \\
\hline \multicolumn{2}{|l|}{ Read online: } \\
\hline 口idn & $\begin{array}{l}\text { Scan this QR } \\
\text { code with your } \\
\text { smart phone or } \\
\text { mobile device } \\
\text { to read online. }\end{array}$ \\
\hline
\end{tabular}

Purpose: This report is on a team effort to advise the Department of Trade and Industry on the development of a regulatory framework for the auditing of Financial, Management. Performance and Social Reporting Systems for co-operatives.

Orientation: There was no framework in place prescribing requirements for reporting on financial, management and social performance of co-operatives. As a result, the team assisted the Department of Trade and Industry with the development of a proposed reporting framework with reference to international best practices and existing financial reporting frameworks.

Findings: The research performed showed that existing reporting frameworks and practices do not meet the reporting requirements of co-operatives in all aspects because of the different nature of co-operatives as opposed to shareholder-owned entities.

\section{Background}

South Africa is an emerging economy and as such joined the BRIC group in 2010 to form the new BRICS (Brazil, Russia, India, China and South Africa) grouping (South African Government 2015). BRICS is an association of leading emerging economies. With the possible exception of Russia, the BRICS members are all developing or newly industrialised countries (Kegley 2012).

The Growth and Development Summit, held in July 2003 in South Africa, endorsed special measures to support co-operatives as part of a strategy for job creation and poverty alleviation in the South African economy (Philip 2003:14). As part of this strategy, the Department of Trade and Industry (DTI) was tasked with creating an enabling environment for co-operatives through legal and other frameworks.

According to the DTI (2011:25), the co-operative sector in South Africa was traditionally aimed at promoting farming communities in South Africa. The co-operative sector was governed by the Co-Operatives Society Acts of 1922 and 1939, as well as the 1981 Co-Operatives Act.

It is explained in The Co-operative Development Policy for South Africa that South Africa has a history of an unequal allocation of prosperity and work opportunities amongst different races. The expansion of upcoming businesses and a broader spread in ownership in such businesses became a great priority in the South African economic policy. This is to ensure an increase in equal wealth distribution and socio-economic development. It is recognised that a strong and self-maintaining co-operative drive in South Africa can serve as a cure for socio-economic problems, such as unemployment, limited access to resources and unequal distribution of wealth (DTI 2004:4).

The South African Co-Operatives Act No 14 of 2005 (hereafter refer to as the Act) was promulgated into law in August 2005 and the Co-Operative Amendment Bill was drafted at the end of 2010 (hereafter refer to as the Bill). The amendments are according to the Bill, inter alia, aimed at the alignment of the Act with the International Labour Organisation Recommendation 193 of 2002. These amendments include the principles of co-operatives, to regulate the audit and financial reporting of co-operatives and to establish training academies for co-operatives in South Africa.

In order to effectively implement the legislation, regulations were also drafted during 2006. The regulations were approved and signed by the Minister and the proclamation in terms of the 
Co-Operatives Act took place in May 2007. By 01 March 2009, more than 43062 co-operatives were in existence (the DTI 2012:35).

In 2010, the DTI, after consultation with various stakeholders, identified some crucial gaps in the legislation. One area that required attention was the development of a regulatory framework for the financial, management performance and social reporting systems for co-operatives (DTI 2010:1). The regulatory framework has been published in the Amended Co-Operative Regulations, 2010. The Amended Co-Operative Regulations, 2010 has during 2012 been published for public comment.

The authors of the paper were appointed to prepare a paper on the possible frameworks as well as best practices in other countries as part of the development of the Amended CoOperative Regulations, 2010.

The challenges of developing a regulatory framework in a developing country like South Africa are numerous. South Africa has a dual-economy with characteristics of both developed and developing countries.

Emerging co-operatives, which comprise the majority of co-operatives in South Africa, are challenged by issues, which include limited access to funds, members with insufficient essential skills (DTI 2004:6), leading to noncompliance with laws and regulations, poor record keeping and poor monitoring of their performance and development.

On the other hand, some of the co-operatives in the economy have in the past been strongly supported by the state (DTI 2004:6) and are therefore likely to be wealthier, with a number of stakeholders which are reliant on these co-operatives.

Challenges in the development of a comprehensive regulatory framework are therefore inevitable because of the wide spread in nature and size of co-operatives.

\section{Research objectives}

The objective of the project was to assist the DTI, in conjunction with other stakeholders, by drafting a regulatory framework that deals with the financial, management and social reporting systems (auditing) of co-operatives. The aim for the framework is to form part of broader regulations for the Co-operatives Amendment Act, no 14 of 2005.

\section{Methodology Literature review}

The research consisted of a literature review of secondary data. A critical examination of international best practices in Canada, Australia, Kenya and Malaysia was carried out as a starting point for the project. Malaysia and Kenya were identified as developing countries, whilst Canada and Australia were identified as developed countries for benchmarking.
Certain topics that would be critical to cover in an auditing environment were selected and were used to critically analyse the following Acts and related literature:

- Co-Operatives Act, 2005 (Act No. 14 of 2005).

- Co-Operatives Amendment Bill, 2012.

- Companies Act, 2008 (Act No. 71 of 2008).

- Regulations to the Companies Act.

- Close Corporations Act, 1984 (Act No. 69 of 1984).

- Labour Relations Act, 1995 (Act No. 66 of 1995).

- Auditing Professions Act, 2005 (Act No. 26 of 2005).

- International Financial Reporting Standards (IFRS).

- International Financial Reporting Standards for Small and Medium Enterprises (IFRS for SMEs).

- International Standards of Assurance Engagements (ISAE 3000).

- International Standards for Review Engagements (ISRE 2400).

- King III Report on Corporate Governance in South Africa.

Academic research performed on accounting and reporting of co-operatives has together with the above-mentioned practices, laws, regulations and standards been evaluated during three different phases of the project. The analysis, findings and conclusions relating to each phase are documented under section 4 of the article.

\section{Focus group}

In order to accommodate and involve stakeholders, it was decided to involve them by following a focus group approach. A focus group approach was regarded as a sound research methodology for the development of the proposed regulatory framework as required by the DTI.

A focus group is defined by Cooper and Schindler (2006) as a: panel of people (typically made up of six to ten participants), led by a trained moderator, who meet for 90 minutes to two hours. The facilitator or moderator uses group dynamics principles to focus or guide the group in an exchange of ideas, feelings and experiences in a specific topic. (p. 212)

The topic under discussion was the development of a regulatory framework for the financial, management performance and social reporting systems for co-operatives (auditing) (DTI 2010). The Co-Operatives Development Unit of the DTI acted as the moderator of the focus group.

The authors of the paper were responsible to develop a regulatory framework in legal format to be included in the Amended Co-Operative Regulations, 2010. The authors' findings, as well as the suggested regulatory framework, were documented in discussion documents, which were proposed to relevant stakeholders to examine the viability of the suggested framework.

The focus group consisted of the following parties:

- South African Institute of Chartered Accountants (SAICA).

- Independent Regulatory Board for Auditors. 
- South African Institute of Professional Accountants.

- German Co-operative and Raiffeisen Confederation (Deutscher Genossenschafts und Raiffelsenverband).

- Department of Trade and Industry.

- Business Enterprises, University of Pretoria.

SAICA and Independent Regulatory Board for Auditors are also members of the International Federation of Accountants. The general public was initially not invited as they would be given the opportunity to comment on the final draft regulations.

The project was carried out in four different phases. Phase one involved a discussion of the scope and to clarify the work schedule and deliverables (Nieman, Plant \& Fouché 2011a). Phase two involved the identification of challenges and solutions for the development of a regulatory framework in a dual-economy as discussed in section 4.2 of the document. Phase three required the development of a regulating framework and auditing requirements for different categories of co-operatives in South Africa and is discussed in section 4.3 in the document. Phase four was mainly used to achieve consensus on a regulatory framework by the focus group and the conversion of the final proposed document into a legal format.

\section{Trustworthiness of focus group data}

Lincoln and Guba (in Morrison-Beedy et al. 2001:51) suggest techniques for establishing trustworthiness of data gathered by means of focus groups such as a detailed audit trail, prompt preparation of transcripts and a detailed interview guide. Trustworthiness of data was ensured during this project by means of clear meeting agendas as well as prompt distribution and feedback on minutes of meetings after each focus group session.

\section{Discussion and findings Phase 1: Terms of reference}

The terms of reference of the project required the development of a regulatory framework that deals with the financial, management performance and social reporting systems of co-operatives (auditing) (DTI 2010).

It was soon discovered by the focus group that no specific reporting framework is prescribed for financial, management performance and social reporting of co-operatives in South Africa. However, the development of auditing requirements was not possible as an audit requires a criterion to measure the subject matter against. The development of a regulatory framework was therefore essential before any audit requirements could be developed.

\section{Phase 2: Regulatory framework for the financial reporting system}

\section{Introduction}

It is assumed that the objective of general purpose financial reporting is to provide financial information about the reporting entity that is useful to existing and potential investors, lenders and other creditors in making decisions about providing resources to the entity (International Accounting Standards Board 2011:A19).

However, it appeared that this objective is not necessarily fulfilled by the financial reporting of co-operatives in South Africa. The focus group could identify during early discussions that no specific regulatory financial reporting framework for co-operatives was prescribed by legislation in South Africa. The lack thereof would obfuscate the performance of an audit on the financial affairs as no criterion is defined to measure the financial affairs of the co-operative. (Nieman, Plant \& Fouché 2011b:3).

International best practices of the governance of co-operatives and other types of entities were investigated, as discussed in part 3.1, serving as guidance for the development of a reporting framework for co-operatives in South Africa. However, it was challenging to identify an economy with the same characteristics as the South African economy with an existing regulatory framework for co-operatives. The resolution was hence to refer to developed countries as a benchmark. Countries such as Germany, Canada (Fouché 2014:56, 66), Australia and the United States are the only countries who have investigated regulatory frameworks specifically for co-operatives.

Existing financial reporting frameworks were considered but are not necessarily appropriate for the application by a co-operative. This observation was later confirmed by PoloGarrido and Marí-Vidal (2011), who are of the opinion that the objectives of a co-operative differ from other entities and the necessity of a different financial reporting framework has been investigated since the initial presence of cooperatives.

The need of a Statement of Recommended Practice for CoOperatives was also identified by Robb (2008) because of the fact that:

Co-operatives operate on the principles of user-ownership, usercontrol and proportional distribution. They differ in many significant ways from investor-owned corporations. Consequently there is a need for a specific Conceptual Framework for cooperatives. (pp. 2-4)

\section{Existing financial reporting frameworks}

Existing financial reporting frameworks were evaluated for the application by co-operatives because of the absence of a financial reporting framework specifically designed for co-operatives.

Nieman et al. (2011b:5) considered the application of SA GAAP for co-operatives in South Africa but was advised by Choonara (2011) that SA GAAP will be withdrawn from South Africa from 2012. All entities in South Africa became responsible for the adoption of other appropriate financial reporting frameworks such as IFRS or IFRS for SMEs after 
Choonara's prediction was confirmed during March 2012 - the Accounting Practices Board and Financial Reporting Standards Council announced that the withdrawal of SA GAAP would become applicable for financial years from 01 December 2012 (SAICA 2012).

Furthermore, the application of IFRS for SMEs has been under investigation since 2004 and the status of the investigation was identified by the discussion group and the following came to their attention (Nieman et al. 2011b)

The International Accounting Standards Board (IASB) suggested the application of International Financial Reporting Standards for Small and Medium Enterprises (IFRS for SMEs) as a financial reporting framework for co-operatives. The International CoOperative Alliance (ICA 2004) expressed their concern that the application thereof will not be appropriate or beneficial for co-operatives. (p. 5)

The following, amongst other reasons, were conveyed by the ICA in support of their opinion:

IFRS for SMEs is based on the complete IFRS and will therefore require special knowledge of IFRS. The application thereof will be considerably more difficult for small and medium cooperatives as opposed to companies with better developed human and financial resources. Therefore compliance might therefore become a pricy exercise.

The application of IFRIC 2 will in some instances lead to co-operative member shares being classified as a liability and not as equity as before. This can have serious consequences on their business.

The application of Section 18 of the Exposure Draft, the accounting method for business combinations under IFRS for SMEs, can lead to mergers between co-operatives not accounted for appropriately. This is because of the fact that the application thereof will require the purchase method and not the pooling of interest method being applied by cooperatives, which will result in a true reflection of the legal form of the transaction.

\section{Operational guide for co-operative audit}

Guidance on the audit function of co-operatives in the form of an Operational Guide for Co-operative Audit, published by the Deutscher Genossenschafts und Raiffelsenverband, was also investigated by the focus group in addition to existing financial reporting frameworks. This was carried out in an attempt to obtain guidance on a regulatory framework for co-operatives. However, it was established that this guide is limited to administrative guidance on the performance of an audit on co-operatives. No regulatory framework specific to co-operatives is specifically described in the document either (Deutscher Genossenschafts und Raiffelsenverband 2010).

The focus group advised the DTI that a great need exists for the development of a regulatory framework in the form of an annual return specifically for emerging co-operatives.
The purpose of such an annual return is to make it practical for co-operatives with limited access to accounting knowledge and employees with limited education to report on the financial status and performance of the co-operative.

The annual return of co-operatives in the United Kingdom was investigated in an attempt to obtain an understanding of the desired content of such an annual return. This annual return includes an assortment of statistics as indication of Commercial Performance, Compliance with Accounting Standards, Environmental and Social Performance and Corporate Governance (T. Harwood [Co-Operatives UK] pers. comm., 19 October 2011).

However, the intention is that the annual return as recommended by the focus group should be on a more basic level to make it user friendly for the application by emerging co-operatives.

The initiation of a similar focus group with defined terms of reference directed at the development of such an annual return was also recommended to the DTI. However, it was not possible for this focus group to develop an annual return because of the limited scope of the terms of reference of the project.

\section{Phase 3: Selecting an appropriate financial, management performance and social reporting framework for co-operatives in South Africa}

\section{Introduction}

The appropriate framework for the financial, management performance and social reporting of co-operatives is selected with specific reference to reporting as well assurance requirements.

\section{Financial reporting}

Co-operatives in South Africa comprise according to Section 1 of the Co-Operatives Amendment Act (6/2013) the following categories:

- primary co-operatives;

- secondary co-operatives and

- national apex co-operatives.

All categories of co-operatives in South Africa can be classified mainly as emerging co-operatives and established co-operatives. The current emphasis of the government is to ensure growth in the emerging co-operatives (DTI 2004:6).

The adoption of one financial reporting framework for cooperatives in South Africa will hence not be feasible because of a variety of types of co-operatives in South Africa.

\section{Categorisation of co-operatives}

The focus group recommended specific financial reporting frameworks for secondary, national apex and primary cooperatives, as defined by Section 1 of the Co-Operatives 
Amendment Act (6/2013). Primary co-operatives were further categorised as small, medium and large primary co-operatives. Further classification was carried out according to annual revenue and asset bases in an attempt to identify financial reporting frameworks that will be appropriate for various sizes of primary co-operatives.

The above-mentioned categorisation of co-operatives as well as the recommended financial reporting framework for each category is as set out in Table 1.

\section{Assurance on the financial statements}

The size of the co-operative and number of stakeholders were considered where it was recommended whether a cooperative should be subject to a reasonable level (audit) or limited level (independent review) of assurance. The audit and independent review requirements of the Companies Act No. 71 of 2008 were also referred to as a benchmark.

Section 30 of the Companies Act $(71 / 2008)$ inter alia states that public and state-owned companies are subject to an audit. It is also stated in this section that companies other than public and state-owned companies will in some instances, where the public interest of the company is limited, only be subject to an independent review. Aspects such as the size of the workforce, annual turnover and nature and extent of activities influence the so-called public interest of the company according to Section 30(2)(b)(i) of the Companies Act (71/2008).

This approach was also considered by the focus group when recommendations for the audit and independent review function of co-operatives were evaluated. It has been assumed that the category of co-operative will be an indication of the public interest of the co-operative. These considerations resulted in the assurance requirements as set out in Table 2.

\section{Co-operative management performance reporting and assurance system}

In developing the regulations for the management performance reporting system, the work of the DGRV (German Co-Operative and Raffeisen Confederation 2010) was used as point of departure. This was carried out primarily because it was originated as a guideline in Pretoria, South Africa, for use in the country. Numerous publications of the Philippines, India, Canada and Brazil were scrutinised for additional guidelines.

It was decided by the focus group that the management performance reporting should focus on the achievement of the objectives of the relevant co-operative and should cover the following areas:

- whether proper written policies and procedures are in place for employee recruitment, administration, finance, procurement, the granting of loans and/or credit;

- whether all policies and procedures laid down by the members and the board of directors are being adhered to;

- whether management decisions are supported by proper planning and calculations;

- whether board members are democratically elected;

- the manner in which duties and authorities are delegated;

- whether a proper realistic business plan is in place, adhered to and reviewed on a regular basis;

- whether board of directors and general meeting decisions are implemented and communicated and

- whether a register of declarations of interest by employees and board members is in place and updated regularly.

It was agreed that all co-operatives should be obliged to include a management performance review as part of its annual accounting report covering the aspects set out above. The management performance review will be subject to the same level of assurance as required by the standards set out in ISAE 3000.

TABLE 1: Financial reporting framework by category of co-operative.

Primary: Medium (co-operatives with individual asset bases of more than R1000.00 and individual annual revenue of less than R1000 000.00)

Primary: Large (co-operatives with individual asset bases of more than R1000.00 and individual annual revenue of more than R1000 000.00)

Secondary and national apex

IFRS for SMEs.

IFRS for SMEs.

Financial reporting framework as prescribed by the Registrar. IFRS for SMEs where secondary and national apex body received money from the government.

Source: Nieman, G.H., Plant, K. \& Fouché, K.B., 2011c, Project: Development of a regulatory framework for the financial, management, performance and social reporting systems for co-operatives (auditing of co-operatives): Phase 3: Final Draft, Business Enterprises, the University of Pretoria, Pretoria

IFRS, International Financial Reporting Standards; SME, Small and Medium Enterprises.

U\$1, R8.13.

TABLE 2: Level of assurance by category of co-operative.

\section{Category of co-operative}

Primary: Small (asset bases of less than R1000.00 and individual annual revenue of less than R1000 000.00) Level of assurance

None

Primary: Medium (co-operatives with individual asset bases of more than R1000.00 and individual annual revenue of less than R1000 000.00)

Primary: Large (co-operatives with individual asset bases of more than R1000.00 and individual annual revenue of more than R1000 000.00)

Independent review

Audit

Secondary and national apex

Audit

Source: Nieman, G.H., Plant, K. \& Fouché, K.B., 2011c, Project: Development of a regulatory framework for the financial, management, performance and social reporting systems for co-operatives (auditing of co-operatives): Phase 3: Final Draft, Business Enterprises, the University of Pretoria, Pretoria

U\$1, R8.13. 


\section{Co-operative social reporting and assurance system}

The social audit has been adopted by a number of cooperatives worldwide, namely Canada, Denmark, Sweden, United Kingdom and Italy (VICTO 1999:51). A number of guidelines were scrutinised, but the VICTO guideline was the most comprehensive as it focused on the seven principles of co-operatives, namely:

- voluntary and open membership;

- democratic member control;

- member economic participation;

- autonomy and independence;

- education, training and information;

- cooperation amongst co-operatives and

- concern for the community (ICA 2010; VICTO 1999:56-62).

The focus group agreed that all co-operatives should be obliged to include a social review as part of their annual accounting report that assesses the social impact and ethical performance regarding the co-operative's stated vision, mission, goals and code of social responsibility. The report will conclude whether the relevant co-operative complies with the assessment criteria as defined in the objectives of such social review. The framework for the review is the particular co-operative's constitution.

The focus group has in addition to this advised that the following guidelines in respect of the framework as well as the assurance should be included:

The objective of the social review is to assess the social impact and ethical performance regarding the co-operative's stated vision, mission, goals and code of social responsibility.

The report will conclude whether the relevant co-operative complies with the assessment criteria as defined in the objectives of such social review.

The framework for the review is the particular co-operative's constitution.

Such social review shall be subject to the same level of assurance as required by the standards as set out in ISAE 3000.

In addition to what is contained in the constitutions of category $\mathrm{C}$ primary co-operatives, secondary co-operatives and co-operative apex organisations, the aforesaid cooperatives are also obliged to report on the seven principles of co-operatives, according to the VICTO guidelines.

\section{Summary and conclusion}

The process of developing a regulatory framework for the financial, management performance and social reporting systems for co-operatives took nearly 18 months by using a focus group of stakeholders. The draft regulations have now been given to the legal drafters to prepare it for publication in the Government Gazette for public comment.
It is expected that the management performance and social reporting will attract significant comments and possible criticism as these are relatively new concepts. The volume of work involved and possible cost to smaller co-operatives could also be criticised. In view of the DTI's objectives of using co-operatives in economic development and social upliftment, it is imperative that the social impact and management performance of co-operatives be reported on an annual basis.

As with all literature review studies, new information and secondary data become available only as the project progresses. This can change perceptions and possible recommendations. The project team had to conclude with the data at hand because of time limitations.

It is imperative that an IFRS should be developed as a framework for co-operative reporting especially as the IFRS for SMEs does not fully serve the purpose. In the interim, accountants will need to make the best use of the framework available to them.

\section{Acknowledgements Competing interests}

The authors declare that they have no financial or personal relationship(s) that may have inappropriately influenced them in writing this article.

\section{Authors' contributions}

Both authors equally contributed to the research and writing of this article.

\section{References}

Choonara, Y.C. (ychoonara@irba.co.za) 2011. DTI phase 3 report annex a vers2 (2) comments YC reviewed with SvE Comments 20111107(2). [E-mail to:] Cook, L.L. (Laetitia.cook@up.ac.za) 2011-11-10.

Cooper, D.R. \& Schindler, P.S., 2006, Business research methods, 9th edn., McGrawHill/Irwin, Boston, MA.

DTI (Department of Trade and Industry), 2004, A co-operative development strategy for South Africa, Government Printer, Pretoria.

DTI (Department of Trade and Industry), 2010, Terms of reference: Development of a regulatory framework for the financial, management performance and social reporting systems for co-operatives (auditing of co-operatives), The DTI, Pretoria.

DTI (Department of Trade and Industry), 2011, Publication of the integrated strategy on the development and promotion of co-operatives for public comments, Government Printer, Pretoria.

DTI (Department of Trade and Industry), 2012, Publication of the integrated strategy on the development and promotion of co-operatives for public comments, Government Printer, Pretoria.

DGRV (Deutscher Genossenschafts und Raiffelsenverband), 2010, Operational guide for co-operative audit, DGRV, Pretoria.

Fouché, K.B., 2014, 'The status of the financial reporting framework of co-operatives in South Africa', Unpublished M.Com thesis, University of Pretoria, Pretoria.

ICA (International Co-Operative Alliance), 2004, Comment letter on the exposure draft of a proposed IFRS for SMEs, International Co-Operative Alliance, Genève.

ICA (International Co-operative Alliance), 2010, Co-operative identity, values and principles, viewed 29 July 2011, from http://www.ica.coop/coop/principles. html

International Accounting Standards Board, 2011, A guide through IFRS: Conceptua framework, International Accounting Standards Board, London.

Kegley, W.C., 2012, Just the facts 101. World politics: Trend and transformation 2010 2011, 13th edn., Cram 101 Text Book Reviews, Content Technologies Inc, viewed 7 August 2015, from https://books.google.co.za/books 
Morrison-Beedy, D., Côté-Arsenault, D. \& Feinstein, N.F., 2001, 'Maximizing results with focus groups: Moderator', Applied Nursing Research 14(1), 48-53. http:// with focus groups: Moderator, App
dx.doi.org/10.1053/apnr.2001.21081

Nieman, G.H., Plant, K. \& Fouché, K.B., 2011a, Project: Development of a regulatory framework for the financial, management, performance and social reporting systems for co-operatives (auditing of co-operatives): Phase 1: project conceptualization and process outline, Business Enterprises, the University of Pretoria, Pretoria.

Nieman, G.H., Plant, K. \& Fouché, K.B., 2011b, Project: Development of a regulatory framework for the financial, management, performance and social reporting systems for co-operatives (auditing of co-operatives): Phase 2/3 interim discussion paper, Business Enterprises, the University of Pretoria, Pretoria.

Nieman, G.H., Plant, K. \& Fouché, K.B., 2011c, Project: Development of a regulatory framework for the financial, management, performance and social reporting systems for co-operatives (auditing of co-operatives): Phase 3: Final Draft, Business Enterprises, the University of Pretoria, Pretoria.

Philip, K., 2003, Co-operatives in South Africa: Their role in job creation and poverty reduction, South African Foundation, Johannesburg.

Polo-Garrido, F. \& Mari-Vidal, S., 2011, 'History and evolution of accounting in Spanish co-operative societies', Paper presented at International Workshop on Accounting for Co-operatives, Valencia, 29-30th September.
Robb, A., 2008, Towards a conceptual framework for co-operative accounting, Centre of Excellence in Accounting and Reporting for Co-operatives (CEARC), Saint Mary's University, Nova Scotia.

SAICA (South African Institute of Chartered Accountants), 2012, viewed 09 July 2014, from https://www.saica.co.za/Portals/0/Technical/Future\%20of\%20SA\%20GAAP.pdf

South Africa, 2005, Co-Operatives Act No 14 of 2005, Government Gazette 482(27912), viewed 10 February 2011, from http://www.info.gov.za/view/ DownloadFileAction ?id $=67866$

South Africa, 2009, Companies Act, No 71 of 2008, Government Gazette 526(32121) viewed 01 September 2014, from http://www.thedti.gov.za/business_regulation/ acts/companies_act.pdf

South Africa, 2013, Co-Operatives Amendment Act No. 6 of 2013, Government Gazette 578(36729), viewed 28 August 2014, from http://www.cipc.co.za/Coops files/Act6of2013CooperativesAmendAct.pd

South African Government, 2015, 'BRICS (Brazil, Russia, India, China, South Africa)', viewed 21 July 2015, from http://www.gov.za/about-government/brics-brazilrussia-india-china-south-africa

VICTO, 1999, Social audit manual, viewed 17 February 2011, from http://pdfio. $\mathrm{com} / \mathrm{k}-1324535 . \mathrm{htm}$ 